\title{
PEMILIHAN MAD'UW DAKWAH SIRRI NABI PERSPEKTIF SEGMENTASI DAN TARGETING
}

\author{
Alan Surya \& Wahanani Mawasti \\ STID Al-Hadid, Surabaya \\ Alansurya004@gmail.com \& wahananimawasti79@gmail.com
}

\begin{abstract}
Abstrak: Strategi dakwah sirri yang dilakukan Nabi Muhammad selama 3 tahun di Mekkah merupakan sebuah langkah penting bagi dakwah Nabi selanjutnya. Dalam kondisi dakwah yang mula-mula, belum memiliki infrastruktur yang kuat serta tekanan dan penolakan, tetapi Nabi Muhammad sukses mendapatkan mad'uw kurang lebih 38-56 kader Islam. Kesuksesan dakwah sirri Nabi tidak lepas dari kejelihan dan kehati-hatian Nabi dalam memilih dan mengajak orang untuk masuk Islam. Kesuksesan pemilihan prioritas mad'uw pada fase dakwah sirri dapat menjadi inspirasi kita dalam mengembangkan dakwah Islam di masa awal. Untuk itu penelitian ini bertujuan mendeskripsikan pemilihan mad'uw dakwah sirri Nabi Muhammad Saw. menurut tinjauan teori segmentasi dan targeting Philip Kotler. Penelitian ini termasuk penelitian kualitatif deskriptif, studi pustaka dan termasuk penelitian sejarah. Artinya, penelitian ini berorientasi mendeskripsikan (mengulas) segmentasi dan targeting pasar dakwah (mad'uw) Nabi pada masa dakwah sirri 3 tahun di Mekkah dengan sumber data berasal dari buku-buku sejarah yang mengulas dakwah sirri Nabi. Hasil penelitian ini menunjukan bahwa segmentasi yang ada berdasarkan segmentasi demografis, psikografis dan perilaku. Sedangkan, pemilihan mad'uw menggunakan jenis targeting spesialisasi selektif. Adapun pertimbangan dalam membidik mad'uw dakwah antara lain: ukuran pertumbuhan segmen, kapasitas internal Rasulullah, aspek moral serta kemenarikan struktural segmen bagi dakwah jangka panjang.
\end{abstract}

Kata Kunci: dakwah sirri Nabi, segmentasi, targeting.

\begin{abstract}
Da'wah strategy named sirri which was conducted by the prophet Muhammad (PBUH) for 3 years in Mecca constitutes an important step for the next $d a^{\prime}$ wah of the prophet. In early condition of da'wah, the prophet had not had a strong infrastucture and there were a lot of pressures and rejections. Despite the conditions, the prophet Muhammad (PBUH) successfully recruited about 38-56 mad'uw of Islamic cadres. Its success is strongly influenced by the thorough observation and caution of the prophet in selecting and asking people to believe in Islam. The success of prioritizing mad'uw in the phase of da'wah sirri can be our inspiration in developing Islamic ca'wah in the early period. Therefore, this research aims to describe about the selection process of mad'uw in the prophet Muhammad's da'wah sirri based on theories of segmentation and Philip Kotler's targetting. The research includes in descriptive qualitative research, discourse analysis and historical one. It means that the research orientates to describe/analyze segmentation and targetting the market share of da'wah (mad'uw) of the prophet in the 3-year da'wah sirri in the city of Mecca with the data sources from historical books described about the prophet's da'wah sirri. The result of research indicates that segmentations available are demographic, psychographic and attitude segmentations. Meanwhile, the process of selecting mad'uw uses the targeting type of selective specialization. There are considerations in aiming on mad'uw, i.e.: measurement of segmen growth, the prophet's internal capacity, moral aspect and the structural interest of segmen for long term's da'wah.
\end{abstract}

Keywords: the Prophet's da'wah sirrii, segmentation, targeting 


\section{Pendahuluan}

Dakwah merupakan salah satu perintah Allah ditujukan kepada umat Islam yang diwahyukan melalui Alquran dan dicontohkan oleh para rasul Allah. Nabi Muhammad sepanjang hidupnya melakukan dakwah dalam rangka merubah masyarakat jahiliyah menjadi masyarakat yang thoyibah. Dalam sejarah, diketahui strategi dakwah Nabi Muhammad ada yang bersifat dakwah sirri (sembunyi) dan ada yang bersifat dakwah jahri (terbuka). Dakwah Nabi (Muhammad) secara sirri dilakukan selama tiga tahun di Mekkah, dakwah ini dalam bentuk dakwah individu, bil-hikmah dan rahasia. ${ }^{1}$ Meskipun dakwah Nabi bersifat sirri, tetapi hasil yang diperoleh cukup banyak yaitu kurang lebih 40 orang dari berbagai kelas sosial, golongan ini disebut al-Sabiqun al-Awwalun.

Hasil dakwah Nabi Muhammad selama dakwah sirri ini kemudian menjadi salah satu kekuatan untuk melakukan dakwah jahri (terbuka) di Mekkah. Dari dakwah sirri yang dilakukan Nabi Muhammad terbentuklah jemaah golongan mukmin yang memiliki ikatan persaudaraan yang solid, sanggup tolong-menolong dalam menegakkan agama Allah, mereka bekerja mendakwahkan nilai-nilai Islam, menentang, serta mengecam berhalaberhala di Mekkah. Selain itu, dampak dakwah sirri bagi Islam secara jangka panjang adalah berlangsung nilai-nilai Islam yang sampai hari ini, hal ini tidak lepas dari kesuksesan siasat dakwah sirri yang dilakukan Nabi Muhammad.

\footnotetext{
1 Syeikh Safy Al-Rahman Al-Mubarakfuriyy, Sirah Nabawiyah, (Jakarta Timur: Pustaka Al-Kautsar), 71.
}

Tulisan ini memfokuskan pada fenomena pemilihan mad'uw oleh Nabi Muhammad saat dakwah sirri di Mekkah. Adapun pertimbangannya antara lain: Pertama, ketika fase dakwah sirri, Nabi tidak langsung mengajak semua orang untuk masuk ke dalam agama Islam secara terang-terangan tetapi dilakukan secara sembunyi dan bertahap, di antaranya: didahulukan yang dekat dengan Nabi. Dari fenomena ini di mungkinkan bahwa Nabi melakukan

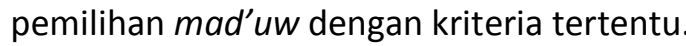
Kedua, Nabi pada dakwah sirri melakukan pemilihan mad'uw dan hasilnya begitu luar biasa dengan loyalitas mad'uw pada Islam yang sangat tinggi, padahal dakwahnya dilakukan dengan kondisi tidak memiliki kekuatan infrastruktur yang besar jika dibandingkan dengan kekuatan sistem penyembah pagan di Mekkah saat itu. Hasil mad'uw yang luar biasa ini tentunya tidak lepas dari ketepatan pemilihan mad'uw dalam proses dakwah sirri di Mekkah. Ketiga, pemilihan mad'uw merupakan salah satu aspek penting dalam menyukseskan dakwah yang dilakukan oleh seorang dai. Pemilihan mad'uw akan menentukan isi, metode dan media dakwah yang sesuai dalam mendakwahkan nilai-nilai Islam. Karakteristik mad'uw yang sudah ditetapkan secara spesifik akan mempermudah perumusan strategi dakwah. Sebagaimana dalam sebuah hadis: "Kami para Nabi diperintahkan untuk berkata dengan manusia mengikut kadar akal mereka".

Bertepatan dengan maksud hadis tersebut di atas, Rahmah Hashim dalam Mariam, menyatakan bahwa cara menyampaikan ilmu adalah berbeda di antara orang tua 
dengan kanak-kanak, orang bandar dengan orang luar bandar, yang berpendidikan tinggi dengan yang berpendidikan rendah, orang Islam dan orang bukan Islam. ${ }^{2} \mathrm{Hal}$ ini menunjukan bahwa pemilihan prioritas mad'uw akan memengaruhi strategi dakwah seorang dai.

Pemilihan mad'uw yang tepat dalam peristiwa dakwah sirri Nabi Muhammad di Mekkah menurut penulis dapat ditinjau dari ilmu pemasaran. Dakwah adalah kegiatan mensyiarkan ajaran Allah, mengajak orang untuk mengikuti perintah Allah dengan cara-cara yang bil-hikmah. Dakwah ibarat sebuah proses memasarkan nilai-nilai pada masyarakat, sehingga dapat disebut dengan kegiatan pemasaran. Pemasaran menurut Philip Kotler adalah kegiatan seperangkat proses organisasi untuk menciptakan, mengomunikasikan, dan menyerahkan nilai pada pelaggan dan mengelola hubungan dengan pelanggan dengan cara yang menguntungkan organisasi dan pemilik modal. ${ }^{3}$ Dalam pemasaran aspek yang diciptakan, dikomunikasikan dapat berupa gagasan, barang dan jasa untuk menciptakan pertukaran yang memuaskan tujuan-tujuan individu dan organisasi. ${ }^{4}$

Dari pernyataan tersebut bisa diketahui bahwa pemasaran tidak hanya terbatas pada barang dan dunia bisnis, tetapi bisa juga berupa gagasan dan jasa, dan dalam dunia dakwah aspek yang ditawarkan adalah gagasan dan jasa, sehingga teori pemasaran dapat diterapkan dalam dunia dakwah. Sedangkan, pemilihan mad'uw dapat disebut juga sebagai kegiatan

\footnotetext{
2 Mariam binti Abd. Majid, "Adaptasi Kaedah Pemasaran Dalam Perancangan dan Pengurusan Dakwah," Jurnal International Research management and innovation Conference, (2014): 397.
}

pemilihan pasar. Untuk itu, ilmu pemasaran digunakan dalam mengkaji kegiatan pemilihan mad'uw yang dilakukan oleh Nabi Muhammad selama dakwah sirri di Mekkah. Teori pemasaran yang digunakan untuk menganalisis aktivitas pemilihan mad'uw pada dakwah sirri di Mekkah yang dilakukan Nabi Muhammad Saw. adalah teori segmentasi dan targeting pasar Philip Kotler. Segmentasi dan targeting adalah tahap pemilihan pasar dan merupakan bagian dari kegiatan manajemen pemasaran. Pemilihan segmentasi dan targeting pasar, juga dapat digunakan dalam konteks organisasi nirlaba, khususnya dalam pemilihan pasar dakwah (mad'uw).

Tulisan ini menggunakan studi kualitatif, deskriptif dengan pendekatan studi pustaka dan sejarah. Dikatakan studi deskriptif karena prosesnya menemukan, menyusun dan menjabarkan temuan data mengenai bentuk segmentasi dan target pasar dakwah (mad'uw) masa dakwah sirri Nabi ketika di Mekkah. Termasuk studi kualitatif dikarenakan beberapa hal, pertama, objek yang diteliti adalah data sejarah dakwah Rasul sehingga peneliti memperlakukan data sesuai yang tersaji (tanpa eksperimen), kedua, untuk memperoleh data, digunakan beberapa sumber data, kemudian mencari kesamaan data yang ada, ketiga, analisis datanya induktif dengan mengumpulkan data dari banyak sumber data kemudian dirangkum menjadi kesimpulan. Hal ini sesuai dengan penjelasan Sugiyono dikatakan bahwa penelitian kualitatif digunakan untuk meneliti pada kondisi objek yang alamiah (bukan eksperimen),

\footnotetext{
3 Philip Kotler, Manajemen Pemasaran Edisi kedua belas jilid 1, (Jakarta: PT. Indeks, 2008), 6.

4 Philip Kotler, Manajemen Pemasaran Edisi I (Jakarta: PT. Prenhalindo, 1997), 13.
} 
dalam hal ini peneliti sebagai instrumen kunci, teknik pengumpulan daya dilakukan secara triangulasi (gabungan), analisis data dilakukan bersifat induktif dan hasil penelitian lebih menekankan makna daripada generalisasi. ${ }^{5}$

Termasuk jenis penelitian studi pustaka sejarah karena yang menjadi sumber data adalah buku literatur, dalam penelitian ini yang menjadi sumber data utama adalah buku-buku sejarah yang menjelaskan dakwah sirri Rasul di Mekkah. Sebagaimana penjelasan Suharsini Arikunto, bahwa penelitian pustaka sumber data berupa tanda-tanda, huruf, gambar, dokumen, paper atau simbol. ${ }^{6}$ Objek kajian dalam tulisan ini adalah data sejarah terkait dakwah sirri Rasul di Mekkah dan pemilihan prioritas mad'uw. Sumber data yang menjadi rujukan utama adalah buku sejarah: (1) Sirah Nabawiyah oleh Ibnu Hisyam, Sirah Nabawiyah Karangan Ibnu Ishaq dan Ibnu Hisyam; (2) Sejarah Hidup Muhammad oleh Muhammad Husain Haikal; (3) Sirah Nabawiyah karangan Syaikh Muhammad Ali Al-Harakan; (4) Sirah Nabawiyah karangan Syaikh Syafiyyurrahman Al-Mubarakfuri; (5) Manhaj Haraki Strategi Pergerakan dan Perjuangan Politik dalam Sirah Nabi Saw. oleh Syaikh Munir Muhammad Al-Ghadban; (6) buku karangan Karen Amstrong yang berjudul Muhammad Prophet for Our Time.

Adapun studi sebelumnya tentang teori pemasaran dalam konteks organisasi dakwah pernah ditulis oleh Mariam binti Abd. Majid dengan judul "Adaptasi Kaedah

\footnotetext{
5 Sugiyono, Memahami Penelitian Kualitatif, (Bandung: CV. Alfabeta, 2008), 1.

6 Suharsini Arikunto, Prosedur Penelitian Suatu Pendekatan Praktik, (Jakarta: PT. Rineka Cipta, 2006), 129.

${ }^{7}$ Mariam, “Adaptasi Kaedah Pemasaran.” 397.
}

Pemasaran Dalam Perancangan dan Pengurusan Dakwah," 7 dalam jurnal tersebut berisi tentang bentuk adaptasi teori pemasaran Philip Kotler jika diterapkan dalam dunia dakwah. Jurnal tersebut menjadi rujukan untuk menganalisis fenomena organisasi dakwah dengan teori pemasaran. Namun, ada perbedaan antara jurnal tersebut dengan tulisan ini. Tulisan ini lebih menekankan pada penggunaan teori pemasaran spesifik pada segmentasi dan targeting Philip Kotler untuk menganalisis pemilihan mad'uw dakwah sirri Nabi Muhammad.

\section{Segmentasi dan Targeting}

\section{Pengertian Segmentasi Pasar}

Pembagian suatu pasar menjadi kelompokkelompok pembeli yang berbeda yang mungkin memerlukan produk atau ramuan pemasaran tersendiri. Perusahaan mengidentifikasi cara-cara untuk melakukan segmentasi pasar dan mengembangkan profil dari segmen-segmen yang dihasilkan itu. ${ }^{8}$ Menurut Sofyan Assauri, segmentasi pasar adalah suatu cara untuk membedakan pasar menurut golongan pembeli, kebutuhan pemakai, motif, perilaku, kebiasaan pembelian, cara penggunaan produk dan tujuan pembelian produk tersebut. ${ }^{9}$

Dari definisi di atas, maka segmentasi pasar dapat disimpulkan sebagai usaha perusahaan dalam mengelompokkan pembeli menjadi kelompok-kelompok yang

\footnotetext{
8 Philip Kotler, Dasar-Dasar Pemasaran Edisi V, (Jakarta: Intermedia, 1991), 299

9 Anggi Sulaiman, "Strategi Pemasaran Produk Tabungan Wadi'ah Bank Mega Syariah," (Skripsi, UIN Syarif Hidayatullah, 2011), 29.
} 
berbeda dan lebih kecil yang dilandaskan karena banyak faktor, dengan tujuan untuk memudahkan perusahaan dalam masuk menjual produk ke karakter pasar tertentu.

\section{Dasar-Dasar Segmentasi}

Menurut Philip Kotler, tidak ada cara tunggal untuk segmentasi suatu pasar. Seseorang pemasar harus mencoba membedakan variabel segmentasi, secara tunggal dan secara kombinasi, dengan harapan untuk mendapatkan cara yang bermanfaat guna melihat struktur pasar. Dasar-dasar segmentasi berdasarkan jenis karakteristik pengelompokannya dapat dibedakan menjadi, pertama, segmentasi geografis menghendaki pembagian pasar menjadi unit-unit geografis seperti bangsa, Negara bagian, wilayah provinsi, kabupaten atau tetangga. Perusahaan memutuskan untuk melakukan kegiatanya di satu atau beberapa daerah geografis atau melakukan kegiatannya pada semua daerah tetapi hanya memberikan perhatian pada variasi dalam kebutuhan dan preferensi geografis. ${ }^{10}$

Kedua, segmentasi demografis adalah suatu proses yang membagi pasar menjadi kelompok-kelompok berdasarkan variabel demografis seperti umur, jenis kelamin, ukuran keluarga, daur hidup keluarga, pendapatan, pekerjaan, pendidikan, agama, ras, kebangsaan. ${ }^{11}$ Ketiga, segmentasi psikografis, pembeli dibagi menjadi beberapa kelompok menurut kelas sosial, gaya hidup, atau karakteristik kepribadian. Orang dalam kelompok demografis yang sama bisa saja mempunyai profil demografi yang berbeda. ${ }^{12}$ Keempat, segmentasi

10 Philip Kotler, Manajemen Pemasaran Edisi XI, (Jakarta: PT. Indeks kelompok gramedia, 2005), 307. 11 lbid. perilaku, pembeli dibagi menjadi kelompokkelompok berdasarkan pengetahuan, sikap, kegunaan, tanggapan mereka terhadap suatu produk. Dalam konteks dakwah, mad'uw dalam merespon aktivitas dakwah baik itu terhadap dai, materi, metode maupun media dakwahnya memiliki berbagai respon. Hal ini dikarenakan tergantung pada kesenangan atau preferensi mereka. ${ }^{13}$

\section{Pengertian Targeting}

Setelah perusahaan mengidentifikasi peluang-peluang segmen pasarnya, ia harus mengevaluasi beragam segmen dan memutuskan berapa banyak dan segmen mana yang akan dibidik, tahap ini yang disebut dengan penetapan target pasar. Sehingga, targeting adalah proses penetapan target pasar. Dalam menetapkan target pasar, ada beberapa jenis pola ada dalam targeting antara lain: (a) Konsentrasi segmen tunggal. Melalui pemasaran yang terkonsentrasi, perusahaan mendapatkan pengetahuan yang kuat tentang kebutuhan segmen dan meraih posisi pasar yang kuat di segmen tersebut, lebih jauh lagi perusahaan menikmati operasi yang ekonomis melalui spesialisasi produk, distribusi dan promosinya; (b) spesialisasi selektif. Perusahaan memilih sejumlah segmen, secara objektif masing-masing segmen menarik dan memadai, mungkin terdapat sedikit atau tidak ada sinergi di antara segmen-segmen tersebut, namun masingmasing segmen berpotensi sebagai penghasil uang; (c) spesialisasi produk, perusahaan menghasilkan produk tertentu yang dijualnya ke beberapa segmen; (d) spesialisasi pasar, dalam hal ini perusahaan

12 Ibid.
13 Ibid. 
berkonsentrasi untuk melayani berbagai kebutuhan kelompok pelanggan tertentu; (e) cakupan seluruh pasar, perusahaan berusaha melayani seluruh kelompok pelanggan dengan menyediakan semua produk yang mungkin mereka butuhkan.

\section{Langkah Targeting}

Pertama, mengevaluasi segmen pasar. Langkah pertama dalam menetapkan targeting pasar adalah mengevaluasi segmen-segmen pasar yang berbeda untuk sebagai landasan dalam menetapkan target pasar. Dalam mengevaluasi segmen pasar, perusahaan (organisasi) haruslah menelaah beberapa pertimbangan antara lain: (1) ukuran dan pertumbuhan pasar yaitu melihat proyeksi laju pertumbuhan penjualan pada segmen tersebut, dan marjin laba (keuntungan) yang dapat diharapkan dari berbagai segmen. Tentu perusahaan ingin memilih segmen-segmen pasar dengan penjualan terakhir yang besar, tingkat pertumbuhan tinggi dan margin laba yang tinggi; (2) kemenarikan struktural pasar yaitu perusahaan (organisasi) menelaah beberapa faktor struktural yang utama yang memengaruhi kemenarikan segmen dalam jangka Panjang; (3) sasaran dan sumber daya yang dimiliki pemasar. Perusahaan atau organisasi mempertimbangkan sasaran dan sumber dayanya sendiri dalam kaitanya dengan segmen itu. Perusahaan dapat menolak segmen yang menarik apabila mereka tidak mempunyai hubungan dengan sasaran jangka panjang perusahaan; pertimbangan etika (moral) dalam memilih segmen tersebut. Pembidikan pasar sasaran mempertimbangkan dampak yang mungkin muncul dari pertentangan pendapat di masyarakat dan keprihatinan publik terhadap segmen pasar organisasi; (5) rencana pengembangan dakwah ke kelompok pasar yang lain yaitu perusahaan mempertimbangkan pesaing dalam tiap segmen yang ada. Para pesaing tidak boleh tahu ke segmen mana perusahaan akan bergerak selanjutnya; (6) dalam evaluasi potensi kerjasama antar segmen pasar, organisasi (perusahaan) biasanya juga mempertimbangkan hubungan antar segmen secara karakteristik tidak boleh terlalu ekstrim berbeda.

Kedua, menetapkan target pasar. Setelah mengevaluasi segmen-segmen yang berbeda, perusahaan dapat mempertimbangkan lima pola pemilihan pasar sasaran yaitu berdasarkan: (1) konsentrasi kelompok pasar tunggal. Perusahaan atau organisasi yang memiliki target pasar pada satu kelompok saja. Perusahaan yang demikian biasanya melakukan pemasaran secara terkonsentrasi yaitu melakukan operasi yang ekonomis melalui spesialisasi produk, distribusi dan promosinya ke satu segmen pasar saja; (2) spesialisasi selektif. Perusahaan memilih sejumlah segmen, secara objektif masing-masing segmen menarik dan memadai, mungkin terdapat sedikit atau tidak ada sinergi di antara segmen-segmen tersebut, namun masingmasing segmen berpotensi sebagai penghasil uang; (3) spesialisasi produk. Perusahaan menghasilkan produk tertentu yang dijualnya ke beberapa kategori kelompok segmen. Kelompok segmen yang dipilih adalah yang memiliki kesamaan secara aspek kebutuhan produk meskipun dari kategori produk yang berbeda; (4) cakupan seluruh pasar. Perusahaan berusaha melayani seluruh kelompok pelanggan dengan menyediakan semua produk yang mungkin mereka butuhkan. 


\section{Konsep Mad'uw (Mitra Dakwah)}

\section{Pengertian dan Jenis Mad'uw}

Mad'uw adalah manusia yang menjadi sasaran dakwah baik individu maupun kelompok, baik yang Islam maupun nonlslam. Tetapi pokok objek adalah manusia secara keseluruhan. Menurut Muhammad Abduh, sebagaimana dikutip oleh M. Natsir mitra dakwah dapat dibagi menjadi tiga, pertama, golongan cerdik cendikiawan yang cinta kebenaran, dan dapat berpikir secara kritis, cepat dapat menangkap arti persoalan. Kedua, golongan awam, orang kebanyakan yang belum dapat berpikir secara kritis dan mendalam, belum menangkap pengertian yang tinggi. Ketiga, golongan tingkat kecerdasan di antara kedua golongan.

Menurut M. Arifin mitra dakwah adalah sebagai berikut: Pertama, dilihat dari segi sosiologi berupa masyarakat pedesaan, kota besar dan kecil, serta masyarakat marginal. Kedua, dilihat dari struktural kelembagaan berupa masyarakat, pemerintah dan keluarga, Ketiga, dilihat dari segi sosiokultural berupa golongan priyai, abangan, dan santri. Keempat, dilihat dari segi usia berupa golongan anak-anak, remaja dan orang tua. Kelima, dilihat dari segi okupasional (profesi) yaitu berupa golongan petani, pedagang, seniman, buruh, pegawai, dsb. Keenam, dilihat dari segi tingkat hidup sosial ekonomis berupa golongan orang kaya, menengah dan miskin. Ketujuh, dilihat dari segi jenis kelamin berupa golongan wanita, pria. Kedelapan, dilihat dari segi khusus berupa golongan masyarakat tuna susila, tuna wisma, tuna karya, narapidana. ${ }^{14}$

\section{Konseptualisasi Segmentasi dan} Targeting terhadap Pemilihan Mad'uw Dakwah

Konsep segmentasi dan targeting yang digunakan dalam proses analisis data berasal dari teori segmentasi dan targeting pada konteks organisasi bisnis. Sehingga perlu dikonseptualisasikan menjadi itemitem segmentasi dan targeting dalam konteks dakwah yaitu proses pemilihan prioritas mad'uw, yaitu sebagai berikut:

Tabel 1 - Konseptualisasi Segmentasi dan Targeting dalam Pemilihan Prioritas Mad'uw

\begin{tabular}{l|l}
\hline \multicolumn{1}{c|}{ Variabel } & \multicolumn{1}{c}{ Konseptualisasi dalam Pemilihan Prioritas Mad'uw } \\
\hline Segmentasi & $\begin{array}{l}\text { Nabi Muhammad membagi atau menggolongkan mad'uw berdasarkan kriteria } \\
\text { tertentu sebelum menetapkan secara spesifik mad'uw sasaran, kriteria tersebut } \\
\text { antara lain: }\end{array}$ \\
& $\begin{array}{l}\text { a. segmentasi geografis. } \\
\text { b. segmentasi demografis. } \\
\text { c. segmentasi psikografis. } \\
\text { d. segmentasi perilaku. }\end{array}$ \\
& $\begin{array}{l}\text { Nabi Muhammad menetapkan target mad'uw yang hendak didakwahi dengan jenis } \\
\text { kelompok target tertentu, misalnya menarget mad'uw secara spesialisasi } \\
\text { terkonsentrasi (kelompok mad'uw tunggal), spesialisasi secara selektif (memilih }\end{array}$ \\
\hline
\end{tabular}

\footnotetext{
${ }^{14}$ Dwi Wahyuni Asriani, "Strategi Positioning Radio Gema Annisa Sebagai Radio Dakwah," (Skripsi, UIN Syarif Hidayatullah, Jakarta, 2009).
} 
sejumlah kelompok mad'uw yang berpotensi tertarik mengikuti ajaran Islam), membidik seluruh segmen mad'uw, dan spesialisasi produk (membidik segmen yang memiliki kebutuhan produk sesuai dengan karakteristik produknya).

Nabi Muhammad dalam menetapkan target mad'uw yang hendak didakwahi mempertimbangkan beberapa aspek antara lain:

a. Mempertimbangkan ukuran dan pertumbuhan mad'uw untuk mencapai tujuan yang diharapkan (potensi penerimanaan mad'uw) pada ajaran yang dibawa oleh Rasulullah).

b. Mempertimbangkan kemenarikan struktural mad'uw yaitu Rasulullah menelaah beberapa faktor struktural yang utama yang memengaruhi kemenarikan (keuntungan - keuntungan) membidik segmen tersebut dalam jangka panjang.

c. Mempertimbangkan kemampuan Rasulullah dalam mendakwahkan ajaran pada target mad'uw yang dibidik. Selain itu, dalam membidik mad'uw Rasulullah mempertimbangkan potensi kesamaan dengan karakteristik ajaran yang dibawanya dan dipandang sasaran mad'uw yang dibidik tersebut tidak akan membawa masalah pada tujuan perkembangan Islam di masa mendatang.

d. Rasulullah dalam membidik mad'uw mempertimbangkan aspek moral yaitu potensi pandangan masyarakat jika Rasulullah membidik pasar.

e. Rasulullah dalam menetapkan target pasar dengan mempertimbangkan kondisi pesaing dalam segmen pasar yang dibidik.

f. Rasulullah dalam menetapkan mad'uw yang dibidik mempertimbangkan evaluasi potensi kerjasama antar segmen dakwah, yaitu mempertimbangkan hubungan antar segmen secara karakteristik tidak boleh terlalu ekstrim berbeda.

\section{Sekilas Tentang Dakwah Sirri Nabi Muhammad}

Dakwah sirri dilakukan Nabi Muhammad dilakukan dengan cara sembunyi-sembunyi dan perorangan. Dari proses dakwah sirri lahirnya sekelompok orang-orang muslim yang memiliki militansi besar pada Islam dan senantiasa menguatkan hubungan persaudaraan serta bahu-membahu memberikan pertolongan. 15 Kegiatan berdakwah secara sembunyi-sembunyi ini berlangsung kurang lebih selama tiga tahun sampai Allah menurunkan wahyu Alquran surah Alhijr: 94 yang memerintahkan untuk dakwah secara terbuka, mengumumkan keimanan dan mengajak kepada ajaran Tuhan kepada semua masyarakat Mekkah

\footnotetext{
${ }^{15}$ Al-Mubarakfuri, Sirah Nabawiyah., 76.
}

dan sekaligus sebagai pertanda berakhirnya masa dakwah sirri Nabi di Mekkah. ${ }^{16}$

Dalam dakwah sirri ada beberapa tahap dakwah yang dilakukan Nabi Muhammad antara lain, pertama kali mendakwahi istri Nabi, yaitu Khadijah binti Khuwailid. Dakwah terhadap Khadijah dilakukan sesaat setelah Nabi menerima wahyu pertama sebagai orang terdekat untuk menceritakan kejadian yang dialami oleh Nabi. Khadijah menyatakan keimanan dan masuk Islam karena ia sudah mengenal Muhammad benar. Selama hidupnya laki-laki itu selalu jujur, orang berjiwa besar ia dan selalu berbuat kebaikan dengan penuh rasa kasihsayang. Selama dalam tahannuth (menyepi, merenung), dilihatnya betapa besar

\footnotetext{
16 M. Husain Haekal, Sejarah Hidup Muhhamad. (Jakarta: PT. Mitra Kerjaya Indo, 2011), 88-90.
} 
kecenderungannya kepada kebenaran, dan hanya kebenaran semata-mata.

Dakwah berikutnya dilakukan setelah Allah menurunkan perintah pertama untuk berdakwah yaitu: "Hai Orang yang berselimut! Bangunlah dan sampaikan peringatan. Dan Tuhanmu agungkanlah. Pakaianmu bersihkanlah. Dan perbuatan dosa tinggalkanlah. Jangan kau memberi, karena ingin menerima lebih banyak. Dan demi Tuhanmu, tabahkan hatimu." (QS. Almudatsir (74): 1-7). Setelah muncul perintah dakwah, Nabi Muhammad berpikir mengajak petinggi (golongan atas) Quraisy supaya turut beriman, padahal Nabi Muhammad tahu benar mereka sangat kuat mempertahankan kebatilan itu. Mereka bersedia berperang dan mati berhala. Kaum Quraisy mempertahankan pandangan elitis dan aristokratiknya dan tentunya berharap Tuhan akan memilih seorang karim keturunan baik-baik dari salah satu klan yang lebih tinggi, bukan seorang anggota minor klan Hasyim. Ketika melihat ajaran yang dibawa oleh Nabi Muhammad dapat berakibat memecah solidaritas keluarga, tentu saja ini menyedihkan Nabi Muhammad. Solidaritas keluarga merupakan nilai yang suci, dan sebagaimana setiap orang arab, beliau menghormati tetua suku dan klannya. Beliau berharap mendapat dukungan dari kalangan atas, tetapi generasi yang lebih mudalah yang segera merespon pesan yang disampaikan Muhammad. ${ }^{17}$ Generasi muda yang awal kali merespon di antaranya adalah Ali bin Abi Thalib Dan Zaid Bin Haritsa.

\footnotetext{
17 Karen Amstrong, Muhammad Prophet For Our Time, (Jakarta: Mizan, 2006), 93.
}

Ali bin Abi Thalib masuk Islam saat mengetahui Nabi dan Khadijah melaksanakan salat, lalu Nabi Muhammad pun mengajak sepupunya itu beribadat kepada Allah semata tiada bersekutu serta menerima agama yang dibawa Nabi utusanNya dengan meninggalkan berhala-berhala semacam Lat dan 'Uzza. Muhammad lalu membacakan beberapa ayat Alquran. Kemudian masuk Islam pula Zaid bin Haritha, bekas budak Nabi. Dengan demikian Islam masih terbatas hanya dalam lingkungan keluarga Muhammad: dia sendiri, isterinya, kemenakannya dan bekas budaknya yang telah diangkatnya menjadi anak angkat.

Dakwah selanjutnya dilakukan pada sahabat-sahabat terdekat Nabi Muhammad Saw. Hal itu dilakukan karena Rasulullah tahu benar, betapa kerasnya masyarakat Quraisy itu dan betapa pula kuatnya mereka berpegang pada berhala yang disembahsembah nenek moyang mereka itu. Pada akhirnya Rasulullah memutuskan untuk berdakwah kepada orang-orang yang paling dekat dengan beliau, anggota keluarganya, dan sahabat-sahabat karib beliau. ${ }^{18}$ Rasulullah menyeru mereka kepada Islam, menyeru pada siapapun yang dipandang memiliki kebaikan, yang beliau kenal secara baik dan mereka mengenal beliau secara baik, yaitu mereka yang memang diketahui mencintai kebaikan dan kebenaran, mengenal kejujuran dan kelurusan Rasulullah. ${ }^{19}$ Maka mereka yang diseru ini langsung memenuhi seruan Rasulullah, mereka ini dikenal dengan golongan Assabiqunal Awwalun, yaitu istri beliau Khadijah binti Khuwailid, bekas budak

\footnotetext{
${ }^{18}$ Al-Mubarakfuri, Sirah Nabawiyah., 73.

19 lbid.
} 
Rasulullah Zaid bin Haritsah bin Syuhrabil AlKalby, Ali bin Abu Thalib dan Abu Bakar Ash Shiddiq. ${ }^{20}$

Sebenarnya, selain menyeru pada golongan As-sabiqunal - Awwalun, saat dakwah sirri di Mekkah, Rasulullah juga sempat mendakwahkan ajarannya kepada pamannya Abu Thalib. Namun, pamannya (Abu Thalib) tidak menerima ajarannya, Abu Thalib berkata: "Wahai keponakanku, sungguh tidak mungkin bagiku bisa meninggalkan agama leluhurku dan tradisi yang biasa mereka lakukan. Meski begitu demi Allah, takkan kubiarkan ada seseorang pun yang berbuat jahat kepadamu selagi aku masih ada. ${ }^{\prime 21}$

Pada tahapan selanjutnya dakwah sirri, Nabi tidak berdakwah seorang diri melainkan dibantu oleh sahabat Abu Bakar. Abu Bakar memiliki kepiawaian dalam mendakwahkan Islam. Dari kalangan masyarakatnya yang dipercayai oleh Abu Bakr diajaknya mereka kepada Islam. Usman bin 'Affan, Abdurrahman bin 'Auf, Talha bin 'Ubaidillah, Sa'd bin Abi Waqqash dan Zubair bin al'Awwam mengikutinya pula menganut Islam. Kemudian menyusul pula Abu 'Ubaida bin Al-Jarrah, dan banyak lagi yang lain dari penduduk Mekkah. Mereka yang sudah Islam itu lalu datang kepada Nabi menyatakan Islamnya, yang selanjutnya menerima ajaran-ajaran agama itu dari $\mathrm{Nabi}$ sendiri. Berdasarkan beberapa referensi, total mad'uw yang masuk Islam masa dakwah sirri tiga tahun di Mekkah lebih dari 30 orang dari berbagai kabilah yang ada di Mekkah.

\footnotetext{
20 Ibid., 74.
}

\section{Analisis Segmentasi dan Targeting Dakwah Sirri Nabi Muhammad}

1. Analisis Segmentasi Pasar Dakwah (Mad'uw)

\section{a. Segmentasi Psikografis}

Dalam teori segmentasi psikografis, pembeli/mad'uw dibagi menjadi beberapa kelompok menurut kelas sosial, gaya hidup, atau karakteristik kepribadian. Orang dalam kelompok demografis yang sama bisa saja mempunyai profil demografi yang berbeda. Dalam membuat segmentasi pasar dakwah (mad'uw), ada beberapa dasar pertimbangan pengelompokan yang kentara yang dilakukan Nabi Muhammad Saw. yaitu: Pertama, berdasarkan psikografis yaitu memilih mad'uw berdasarkan kepribadian dan kedekatan hubungan dengan Rasulullah (baik hubungan keluarga ataupun yang memiliki ikatan pertemanan).

Segmentasi psikografis berdasarkan ikatan kekerabatan/kekeluargaan dan pertemanan dapat dilihat dari mad'uw yang didakwahi Nabi pada dakwah sirri awal - awal, Misalnya dakwah Rasulullah di masa awal lebih berfokus pada istrinya Khadijah, sepupunya yaitu Ali bin Abi Thalib, anak angkat Nabi yaitu Zaid Bin Haritsa, sempat pula berdakwah pada paman Nabi yaitu Abu Thalib, serta teman Nabi Muhammad Saw. Yaitu Abu Bakar As-Shidiq. Al-Mubarakfury menulis, "Pada akhirnya Rasulullah memutuskan untuk berdakwah kepada orang-orang yang paling dekat dengan

\footnotetext{
${ }^{21}$ Ibnu Ishaq - Ibnu Hisyam, Sirah Nabawiyah (Sejarah Lengkap Kehidupan Rasulullah), (Jakarta Timur : Akbar Media Eka Sarana, 2016), 155.
} 
beliau, anggota keluarganya, dan sahabat sahabat karib beliau." 22

Segmentasi Psikografis pada saat dakwah sirri di Mekkah juga berdasarkan kecendrungan kelompok kepribadian yang ada dimasyarakat, hal itu dapat dilihat dari dakwah Nabi kepada Abu Bakar. Nabi melihat Abu Bakar memiliki kepribadian yang baik, cerdas, cenderung pada kebenaran dan merupakan sahabat dekat Nabi sejak kecil, sehingga Nabi Muhammad berani untuk melakukan dakwah kepada Abu Bakar. Dalam sejarah disebutkan bahwa setelah mendapatkan mad'uw dari keluarga inti, Nabi berpikir selanjutnya siapa lagi yang bisa didakwahi diajak masuk Islam. Nabi melihat bahwa masyarakatnya sangat kuat memegang ajaran nenek moyang dan menyembah berhala, maka tidak semua bisa menerima ajaran baru Nabi, malah bisa jadi memusuhi Nabi. Maka kemudian Nabi menetapkan bahwa sasaran dakwah berikutnya adalah mad'uw yang memiliki kedekatan dengan dirinya, berbudi baik, bisa dipercaya, terbuka pemikiranya. Dari beberapa pertimbangan tersebut kemudian Nabi mencoba dakwah kepada Abu Bakar yang merupakan sahabat dekatnya sejak kecil.

Haikal dalam bukunya menjelaskan, "Pada waktu itu Abu Bakr bin Abi Quhafa dari kabilah Taim adalah teman akrab Muhammad. Ia senang sekali kepadanya, karena sudah diketahuinya benar ia sebagai orang yang bersih, jujur dan dapat dipercaya. Oleh karena itu orang dewasa pertama yang diajaknya menyembah Allah Yang Esa dan meninggalkan penyembahan berhala, adalah dia. Juga dia laki-laki

${ }^{22}$ Al-Mubarakfuri, Sirah Nabawiyah., 73.

${ }^{23}$ Ibid., 88-90. pertama tempat dia membukakan isi hatinya akan segala yang dilihat serta wahyu yang diterimanya. Abu Bakr tidak ragu-ragu lagi memenuhi ajakan Muhammad dan beriman pula akan ajakannya itu. Abu Bakar As-Shidiq merupakan seorang pria yang rupawan, kesayangan masyarakatnya, termasuk orang Quraisy yang berketurunan tinggi dan yang banyak mengetahui segala seluk-beluk bangsa itu, yang baik dan yang jahat. Sebagai pedagang dan orang yang berakhlak baik ia cukup terkenal. Kalangan masyarakatnya sendiri yang terkemuka mengenalnya dalam satu bidang saja."23

Selain itu, mad'uw dakwah yang diajak Rasulullah pada masa dakwah sirri juga kebanyakan adalah orang-orang yang telah dikenal Rasulullah dan Sahabat Abu Bakar memiliki kepribadian yang baik khususnya dalam hal kepribadian kejujuran, cinta kebenaran dan memiliki kepedulian yang tinggi pada masyarakat, misalnya: mad'uw dakwah sirri Nabi yang didakwahi oleh dikenal sebagai As- sabiqunal- Awwalun adalah orang-orang yang dikenal di kabilahkabilahnya memiliki kepribadian yang baik dan cenderung memiliki militansi pada agama. Al-Mubarakfury menjelaskan, "Rasulullah menyeru mereka kepada Islam, menyeru pada siapapun yang dipandang memiliki kebaikan, yang beliau kenal secara baik dan mereka mengenal beliau secara baik, yaitu mereka yang memang diketahui mencintai kebaikan dan kebenaran, mengenal kejujuran dan kelurusan Rasulullah. ${ }^{24}$ Maka mereka yang diseru ini ini dikenal dengan golongan As- sabiqunalAwwalun, yaitu istri beliau Khadijah binti Khuwailid, pembantu beliau Zaid bin

${ }^{24}$ Ibid., 73. 
Haritsah bin Syuhrabil Al - Kalby, Ali bin Abu Thalib dan Abu Bakar Ash Shiddiq. ${ }^{25}$

Dakwah sirri berikutnya juga dilakukan Abu Bakar juga mendakwahi teman - teman sesama pedagang yang dikenal dan kerabat satu sukunya (anak - anak Abu Bakar ada yang masuk Islam pula). Kriteria psikografis nampak pada pemilihan mad'uw yang cenderung mengutamakan kepribadian yang baik. Dakwah yang dilakukan Abu Bakar kecendrungan berdakwah pada mad'uw yang memiliki karakteristik yaitu saudagar-saudagar yang merupakan rekan dagang kepercayaannya dan kaum bangsawan Mekkah yang dikenal memiliki kepribadian yang baik, terpercaya, memahami dan mempercayai arti kesucian, kebenaran dan rahmat. ${ }^{26}$ Abu Bakar mengajak teman-temannya, antara lain: Usman bin 'Affan, Abdurrahman bin 'Auf, Thalhah bin 'Abdillah, Sa'id bin Abi Waqqash dan az-Zubair bin al-'Awwam, Abu 'Ubaida bin al-Djarrah. ${ }^{27}$

Dari segmentasi psikografis juga terlihat bahwa ada mad'uw yang dalam demografis sama, namun memiliki karakter psikografis yang berbeda. Misalnya, kalangan ekonomi atas di Mekkah. Sekalipun sama-sama orang yang berharta namun ada yang psikografisnya (kepribadiannya) yang jauh dari kejahiliyaan dan yang sangat dekat dengan kejahiliyaan.

Sehingga, dari data di atas dapat diketahui bahwa Nabi Muhammad mengategorikan segmen mad'uw berdasarkan psikografi yaitu: (1) kelompok mad'uw yang memiliki

\footnotetext{
25 Ibid., 74.

${ }^{26}$ Haekal, Sejarah Hidup Muhhamad., 93.

27 M. Quraish Shihab, Membaca Sirah Nabi

Muhammad Saw. Dalam Sorotan Al-Qur'an Dan
}

hubungan kedekatan, di antaranya kekerabatan/keluarga dan kedekatan karena pertemanan, baik teman dalam pergaulan keseharian maupun teman satu profesi; (2) kelompok mad'uw yang memiliki budi pekerti baik (kecendrungan terbuka pada kebenaran, kejujuran, kebaikan akhlak dan terpercaya) dan kelompok mad'uw yang kepribadiannya kurang baik (jahiliyah).

Pengelompokan secara psikografis yang dilakukan Rasulullah dalam dakwah di sirri di Mekkah ini sangat penting, mengingat adanya perbedaan karakter antara kelompok mad'uw yang memiliki hubungan kedekatan dan tidak. Perbedaan karakter tersebut akan memengaruhi perhitungan terhadap potensi kapasitas segmen tersebut dapat dilayani dengan baik atau tidak. Kelompok mad'uw yang memiliki hubungan kekerabatan atau pertemanan dengan Rasulullah, cenderung lebih dikenali karakteristiknya oleh Rasulullah dan mad'uw tersebut juga telah memiliki pengenalan yang kuat terhadap karakteristik Rasulullah secara personal. Sedangkan, kelompok yang tidak memiliki hubungan kekerabatan tidak memiliki karakter demikian.

Begitupula dengan segmentasi secara psikografi berdasarkan kepribadian (gaya hidup), dalam konteks dakwah yang masih awal dan secara rahasia, pengelompokan mad'uw berdasarkan kepribadian penting untuk dilakukan. Hal ini mengingat dalam konteks masyarakat Arab, ada kelompok mad'uw yang dikenal sangat kuat

Hadits-Hadits Shahih, (Tanggerang : Lentera Hati, 2011), 338. 
mempertahankan tradisi (gaya hidup Jahiliyah) dan ada pula kelompok-kelompok yang memiliki budi pekerti yang baik sehingga lebih mudah diajak pada nilai-nilai Islam yang cenderung baru dan berbeda dari ajaran nenek moyang bangsa Arab.

\section{b. Segmentasi Demografis}

segmentasi demografis adalah suatu proses yang membagi pasar menjadi kelompokkelompok berdasarkan variabel demografis seperti umur, jenis kelamin, ukuran keluarga, daur hidup keluarga, pendapatan, pekerjaan, pendidikan, agama, ras, kebangsaan. Dalam proses dakwah sirri, Nabi Muhammad mengelompokan segmen pasar (mad'uw) secara demografis berdasarkan kelas ekonomi yaitu adanya segmen golongan atas (pemimpin Mekkah) dan golongan bawah (budak-budak). Hal tersebut ditunjukan dari data sebagai berikut: "Setelah muncul perintah dakwah, Nabi Muhammad berpikir bagaimana akan mengajak petinggi (golongan atas) Quraisy supaya turut beriman, padahal Nabi Muhammad tahu benar mereka sangat kuat mempertahankan kebatilan itu. Mereka bersedia berperang dan mati untuk itu." Haikal juga menyatakan bahwa banyak yang mengikuti ajaran Islam di masa dakwah Sirri yang merupakan golongan kaum lemah, orang-orang yang mengalami kesengsaraan dan yang tidak punya Di antara golongan ini antara lain: Amr bin Fuhairah, Bilal bin Abi Rabbah, Sumayyah binti Khayyath, Yasir bin Amir dan lain sebagainya." 28

Nabi melakukan segmentasi pasar dakwah (mad'uw) berdasarkan demografi kelas ekonomi ditunjukan dari munculnya keinginan Nabi berdakwah pada golongan atas (petinggi Mekkah), Nabi memiliki harapan jika pertinggi Quraisy yang masuk Islam maka bisa mempercepat perkembangan dakwah Islam. Namun, Nabi Muhammad juga menyadari bahwa golongan petinggi Quraisy, khususnya para tetua sangat militan terhadap ajaran pagan saat itu. Nabi Muhammad saat dakwah sirri di Mekkah juga melakukan segmentasi demografis berdasarkan usia yaitu dengan mengelompokan golongan tua dan generasi muda. Hal tersebut ditunjukkan data berikut, "Ketika melihat ajaran yang dibawa oleh Nabi Muhammad Saw. dapat berakibat memecah solidaritas keluarga, tentu saja ini menyedihkan Nabi Muhammad Saw. Solidaritas keluarga merupakan nilai yang suci, dan sebagaimana setiap orang arab, beliau menghormati tetua suku dan klanya. Beliau berharap mendapat dukungan dari kalangan atas, tetapi generasi yang lebih mudalah yang segera merespon pesan yang disampaikan Muhammad."

Dari data mad'uw yang didapat saat dakwah sirri, banyak dari kalangan muda yang menjadi mad'uw dakwah Rasulullah. Misalnya di antaranya: Ali bin Abu Thalib, Fathimah binti Al-Khaththab, Zaid bin Haritsa, Zubair bin Awwan dan lain sebagainya. Oleh karena itu, wajar jika dikatakan dalam beberapa buku bahwa saat dakwah sirri di Mekkah, Rasulullah sempat berpikir berdakwah pada golongan tua, akan tetapi golongan muda jauh lebih potensial dan merespon dakwah Rasulullah secara positif.

Pengelompokan berdasarkan demografis hanya berdasarkan pada usia dan tingkatan ekonomi. Nabi tidak mengelompokan

${ }^{28}$ Haekal. Sejarah Hidup Muhhamad., 93. 
mad'uw berdasarkan aspek demografis keturunan/klan. Hal itu ditunjukan dari hasil dakwah Nabi yang hanya pada masyarakat Mekkah dan dari berbagai klan. Nabi tidak membeda-bedakan kategori berdasarkan klan/keturunan. Sehingga, mad'uw yang dihasilkan dapat berasal dari klan mana saja dan masih hanya pada wilayah Mekkah. Mad'uw dakwah sirri di Mekkah, pertama, Bani Hasyim, antara lain: Ali bin Abu Thalib, Ja'far bin Abu Thalib, Ummul Fadhal binti AlHarits, Ubaidah binti Al-Harits, Asma' binti Umais, Khadijah binti Khuwailid. Kedua, Bani Umaiyah antara lain: Utsman bin Affan, Khalid bin Sa'ad, Aminah binti Khalid, Hathib bin Amer, Abdullah bin Jahsy, Abu Ahmad bin Jahsy, Fathimah. Ketiga, Bani Makhzum antara lain: Abu Salamah bin Abdul Asad, lyasy bin Abi Rabi'ah, Asma, Yasir bin Amir, Sumayyah binti Khayyath, Al-Arqam bin Abil Arqam. Keempat, Bani Taim antara lain: Abu Bakar, Thalhah bin Ubaidillah, Amr bin Fuhairah, Bilal bin Abi Rabbah. Kelima, Bani Adi antara lain: Sa'id bin Zaid, Fathimah binti Al-Khaththab, Amir bin Abi Rabi'ah, Na'im bin Abudullah, Waqid bin Abdullah, Khalid bin Al-Bakir, Amir bin Al-bakir dan lyas bin Al-bakir. Keenam, Bani Zuhrah antara lain: Sa'ad bin Abi Waqqash, Abdul Rahman bin Auf, Umar bin Abi Waqqash, Abdullah bin Mas'ud, Al-Muthalib bin Azhar dan Khabab bin Al-Arats. Ketujuh, Bani Sahm antara lain: Khanis bin Huzhafah dan Hafsah binti Umar. Kedelapan, Bani Jameh antara lain: Hathib bin Al-Harits, Fathimah, Khaththab bin AlHarits, Fakihah dan Sa'id bin Utsman. Kesembilan, Bani Asad antara lain: Zubair bin Awwan. Kesepuluh, Bani Amir antara lain: Abu Ubaidah bin Al-Jarrah dan Salith bin Amar. Kesebelas, kabilah lain antara lain Shuhaib bin Sinan, Mas'ud bin Rabi'ah,
Mu'amar bin Habib, Zaid bin Haritsa, Amer bin Abasah, Utsman bin Mazh'un, Qudamah bin Maz'hun, Abdullah bin Maz'hun dan Ramlah. Keseluruhannya berjumlah 56 orang.

Pengelompokan (segmentasi) demografis yang dilakukan oleh Rasulullah berangkat dari adanya karakteristik masyarakat Arab yang memiliki perbedaan karakteristik baik secara kelas ekonomi maupun secara usia. Pertama, kelompok mad'uw berdasarkan demografis usia. Masyarakat Arab usia tua cenderung sangat menjunjung tinggi tradisi nenek moyang (penyembahan berhala, perbudakan, gemar minum khamr), solidaritas keluarga sangat dijunjung tinggi, serta dalam berperilaku sangat mengikuti dan menjunjung tinggi tetua klan (sukunya). Sedangkan kelompok usia muda cenderung tidak terlalu kuat rasa solidaritas kesukuannya dan cenderung masih terbuka dalam menerima perubahan baik pemikiran maupun kebudayaan. ${ }^{29}$ Selain itu, jumlah kelompok usia muda cenderung lebih banyak dibandingkan dengan usia tua. Sebab, satu orang laki-laki Arab bisa memiliki banyak istri dan anak saat itu.

Kedua, kelompok mad'uw berdasarkan demografis kelas ekonomi. Dalam masyarakat Arab terdapat kelompok sosial ekonomi golongan atas yang terdiri dari pembesar-pembesar Quraisy dan pemukapemuka Mekkah. Kelompok golongan ekonomi atas ini, cenderung sangat menjaga tradisi penyembahan berhala yang ada di Mekkah. Hal tersebut dikarenakan mereka adalah golongan yang paling diuntungkan dengan adanya tradisi penyembahan berhala. Dengan adanya tradisi tersebut, Mekkah (Kakbah) berkembang sebagai

29 Ibid., 97. 
tempat ziarah (ibadah) masyarakat dari berbagai wilayah jazirah Arab. Dengan adanya aktivitas ziarah tersebut, masyarakat golongan atas memperoleh banyak keuntungan ekonomi melalui aktivitas perdagangan ataupun melalui aktivitas mengurus Kakbah dan menjamu para tamu yang sedang berziarah. Golongan ekonomi atas ini mendapatkan kemakmuran dan kemewahan dari adanya kegiatan penyembahan pagan di Mekkah. Golongan atas, memiliki pengaruh yang sangat besar pada masyarakat Arab, segala aturan hidup masyarakat dibuat, ditegakan dan diikuti masyarakat berdasarkan kesepakatan kelompok ekonomi atas ini. Kelompok atas ini juga yang memiliki banyak budak dan bisa melakukan apa saja pada budak-budak yang dimiliki.

Sedangkan, kelompok ekonomi bawah banyak didominasi golongan budak. Golongan budak banyak diperlakukan secara tidak manusiawi, mereka dijadikan seperti barang yang diperjualbelikan. Golongan budak memiliki karakter yang paling tidak diuntungkan dengan sistem sosial yang dikembangkan di masyarakat Mekkah. Hidup para budak dipenuhi penderitaan, karena status sosial mereka yang dianggap rendah serta sering kali diperlakukan seenaknya oleh masyarakat golongan atas. Jumlah golongan budak ini cukup banyak di masyarakat Mekkah saat itu.

Segmentasi pasar secara demografis, dalam konteks dakwah sirri juga sangat penting. Mengingat dengan mengetahui kelompokkelompok berdasarkan demografisnya, Nabi dapat mengetahui kecendrungan karakteristiknya dan potensi jumlahnya (mayoritas/minoritas). Sehingga, dapat menjadi pertimbangan target pasar dalam aspek kuantitas jumlah yang dapat diraih apabila membidik atau tidak membidik segmen tersebut serta juga dapat mengetahui potensi ancaman dan peluang dari kecendrungan karakteristiknya.

\section{c. Segmentasi Perilaku}

Segmentasi perilaku, pembeli dibagi menjadi kelompok-kelompok berdasarkan pengetahuan, sikap, kegunaan, tanggapan mereka terhadap suatu produk. Dalam konteks dakwah sirri, Rasulullah mengelompokan perilaku mad'uw berdasarkan potensi tanggapan mad'uw pada ajaran (produk dakwah) yang dibawa oleh Rasulullah. Nabi Muhammad memiliki pandangan bahwa masyarakat Mekkah saat itu terbagi menjadi golongan yang memiliki perilaku militansi yang tinggi terhadap tradisi arab dan yang masih terbuka dengan pandangan baru, hal itu dibuktikan dari data yang menyebutkan, "Setelah muncul perintah dakwah, Nabi Muhammad berpikir bagaimana akan mengajak petinggi (golongan atas) Quraisy supaya turut beriman, padahal Nabi Muhammad tahu benar mereka sangat kuat mempertahankan kebatilan itu. Mereka bersedia berperang dan mati berhala. Kaum Quraisy mempertahankan pandangan elitis dan aristokratiknya dan tentunya berharap Tuhan akan memilih seorang karim keturunan baik-baik dari salah satu klan yang lebih tinggi, bukan seorang anggota minor klan Hasyim." "Nabi membenturkan dengan ajaran yang dibawa, yang dapat berakibat memecah solidaritas keluarga, tentu saja ini menyedihkan Nabi Muhammad Saw. Solidaritas keluarga merupakan nilai yang suci, dan sebagaimana setiap orang arab, beliau menghormati tetua suku dan klanya. Beliau 
berharap mendapat dukungan dari kalangan atas, tetapi generasi yang lebih mudalah yang segera merespon pesan yang disampaikan Muhammad. ${ }^{30}$

Dalam hal potensi sikap dan tanggapan, Nabi Muhammad Saw. melihat bahwa di masyarakat setidaknya ada tiga potensi sikap dan tanggapan yang akan muncul ketika Nabi menyampaikan ajaran Islam yaitu (1) Kelompok yang berpotensi dapat mendukung atau merespon secara positif pandangan yang dibawa oleh Rasulullah; (2) Kelompok yang akan menolak sebab ajaran tersebut dipandang bertentangan dengan tradisi dan pandangan masyarakat selama ini. Kelompok yang berpotensi merespon menolak ajaran ini, ada kemungkinan kuat akan memerangi ajaran yang dibawa oleh Nabi Muhammad;(3) Selain itu, juga ada potensi kelompok yang akan menolak masuk Islam (karena juga memiliki militansi ajaran nenek moyang), namun juga tidak bersikap memerangi Nabi Muhammad. Kelompok itu kemungkinan berasal dari kerabat dekat Nabi (Misalnya: Bani Hasyim dan Bani Muttalib).

Kemudian, Nabi juga melakukan segmentasi perilaku berdasarkan pengetahuan yang dimiliki. Nabi menggolongkan masyarakat Arab, ada kelompok yang memiliki pengetahuan sangat kuat terkait dengan pandangan elitis, aristokratiknya, keluarga/klan merupakan aspek yang suci dan sangat menghormati ketua sukunya. Nabi melihat ajaran elitis ini sangat kuat dimiliki oleh kaum Quraisy dan dapat mengakibatkan penolakan terhadap ajaran yang dibawa Nabi Muhammad. Sebab, ajaran yang dibawa Nabi Muhammad berpotensi memecah belah suku karena ikatan yang dibangun bukanlah ikatan kesukuaan melainkan ikatan akidah. Selain itu, ajaran Islam cenderung tidak menekankan nilai-nilai elitis melainkan keseimbangan.

Dalam konteks dakwah sirri, sumber daya masih sangat terbatas, segmentasi mad'uw berdasarkan perilaku mutlak dibutuhkan. Misalnya seperti yang dilakukan Nabi dengan mensegmenkan mad'uw berdasarkan potensi sikap dan tanggapannya terhadap ajaran Islam. Dengan mengetahui potensi sikap dan tanggapan masyarakat Mekkah terhadap ajaran Islam, Nabi Muhammad dapat secara cermat membidik target pasar agar tidak memicu peperangan apabila dakwah awal dilaksanakan.

\section{Analisis Targeting Pasar (Pemilihan Prioritas Mad'uw) Saat Dakwah Sirri}

a. Jenis Targeting Mad'uw Dakwah Sirri

Setelah mempelajari data sejarah dakwah sirri Rasulullah selama di Mekkah, maka ditemukan adanya kemiripan dasar pertimbangan targeting penetapan mad'uw yang dilakukan Rasulullah dengan konsep targeting pemasaran. Dalam pemilihan mad'uw, Rasulullah cenderung menggunakan penetapan target mad'uw secara spesialisasi selektif yaitu memilih sejumlah segmen, secara objektif masingmasing segmen menarik dan memadai, mungkin terdapat sedikit atau tidak ada sinergi di antara segmen-segmen tersebut, namun masing-masing segmen berpotensi untuk menjadi kader, membantu aktivitas dakwah dan menghasilkan kader yang lain. Segmen mad'uw yang ditarget oleh Nabi

\footnotetext{
${ }^{30}$ Amstrong, Muhammad Prophet., 93.
} 
saat dakwah sirri antara lain, pertama, kelompok masyarakat yang masih memiliki hubungan kedekatan. Nabi memfokuskan pada orang-orang tertentu yang dikenal baik olehnya ataupun kader dakwahnya yang lain. Hubungan kedekatan tersebut baik karena ikatan kekeluargaan ataupun pertemanan. Kedua, kelompok masyarakat bawah (para budak, orang-orang yang sensara dan tidak punya) dan para pemuda. Ketiga, kelompok masyarakat yang terbuka pada ajaran (tradisi) baru dan bukan golongan yang memiliki militansi tinggi pada tradisi ataupun agama sebelumnya. Adapun di antara kelompok yang masih terbuka pandangannya dalam ajaran Islam yaitu saudagar-saudagar dan kaum bangsawan Mekkah yang memiliki kepribadian baik, mengenal arti kesucian, memiliki pemahaman terhadap arti kebenaran, pengampunan dan arti rahmat. Keempat, kelompok masyarakat yang berpotensi responnya mendukung ajaran ataupun sekalipun menolak namun tidak memerangi ajaran Nabi Muhammad.

\section{b. Pertimbangan-Pertimbangan Targeting Dakwah}

Kesuksesan Nabi Muhammad saat dakwah sirri di Mekkah, tidak dapat dilepaskan dari beberapa pertimbangan penting dalam membidik pasar dakwah di masa perjuangan dakwah yang masih awal, sembunyisembunyi dan belum memiliki banyak kekuatan. Pertimbangan targeting dakwahnya antara lain, pertama, pertimbangan kondisi internal. Pemilihan mad'uw secara selektif yang dilakukan Rasulullah juga melihat aspek adanya kesamaan karakter ajaran yang dibawa dengan kepribadian mad'uw, ajaran yang dibawakan Rasulullah yaitu Islam berisikan mengenai penyembahan kepada Tuhan
Yang Esa dan menolak ajaran nenek moyang yang menyembah berhala dan segala macam praktik kehidupan yang sesat. Maka mad'uw yang bisa menerima ajaran perombakan ini haruslah yang masih memiliki pemikiran terbuka, bijaksana, pandai, berwawasan dan tidak sombong terikat dengan kekayaan, kedudukan. Oleh karena itu, Nabi Muhammad cenderung lebih memilih mendakwahi Abu Bakar yang sudah dikenalnya memiliki kepribadian yang baik.

Data lain yang menunjukan pertimbangan kondisi internal Rasulullah dalam melakukan targeting selektif untuk berdakwah pada golongan muda, bisa dilihat pada data sikap Nabi Muhammad setelah menerima surah Almudatsir 1-7. Sebagaimana yang disampaikan Haikal, "Kemudian Jibril membawa perintah supaya aku memberi peringatan kepada umat manusia, mengajak mereka, dan supaya mereka beribadat hanya kepada Allah. Tapi siapa yang akan kuajak? Dan siapa pula yang akan mendengarkan?" Khadijah berusaha menenteramkan hatinya. Cepatcepat ia menceritakan apa yang didengarnya dari Waraqa tadi. Dengan penuh gairah dan bersemangat sekali kemudian ia menyatakan dirinya beriman atas kenabiannya itu. Dengan masuk islamnya Khadijah binti khuwailid, Allah meringankan beban Rasulullah Saw. Sekarang ia jadi memikirkan, bagaimana akan mengajak Quraisy supaya turut beriman; padahal ia tahu benar mereka sangat kuat mempertahankan kebatilan itu. Mereka bersedia berperang dan mati untuk itu. Ditambah lagi mereka masih sekeluarga dan sanak famili yang dekat. Sungguhpun begitu, tetapi mereka dalam kesesatan." 
"Selain itu Muhammad juga menyadari bahwa sebagian besar suku Quraisy akan mendapati hal ini nyaris mustahil untuk diterima. Para utusan Allah semuanya merupakan sosok yang menonjol, para pendiri masyarakat. Sebagian bahkan memiliki mukjizat. Bagaimana mungkin Muhammad meraih kesetaraan dengan Musa dan Isa, kaum Quraisy telah menyaksikan bagaimana beliau dibesarkan, mereka melihat bagaimana beliau mengurusi bisnisnya di pasar, makan dan minum seperti orang lain. Kaum Quraisy mempertahankan pandangan elitis dan aristokratiknya dan tentunya berharap Tuhan akan memilih seorang karim keturunan baik-baik dari salah satu klan yang lebih tinggi, bukan seorang anggota minor klan Hasyim. Ketika melihat ajaran yang dibawa oleh dirinya berakibat memecah solidaritas keluarga, tentu saja ini menyedihkan Nabi Muhammad. Solidaritas keluarga merupakan nilai yang suci, dan sebagaimana setiap orang Arab, beliau menghormati tetua suku dan klanya. Beliau berharap mendapat dukungan dari kalangan atas, tetapi generasi yang lebih mudalah yang segera merespon pesan yang disampaikan Muhammad."

Dari data di atas menunjukan bahwa pada awalnya Nabi berharap dapat berdakwah pada golongan tetua di masyarakat Arab, akan tetapi mengingat kapasitas diri Rasulullah sebagai klan minor Bani Hasyim, maka Rasulullah lebih berpikir untuk mendakwahkan pada generasi muda yang lebih menerima ajarannya.

Penetapan targeting pasar secara selektif juga mempertimbangkan kapasitas dakwah Rasulullah di masa sirri. Saat itu sumber daya sangat kecil, dakwah masa di masa awal serta ancaman dari penyembah ajaran/tradisi sebelumnya sangat kuat. Dengan situasi seperti itu, Rasulullah memilih menggunakan targeting secara selektif yaitu hanya spesifik pada golongan orang-orang yang dipandang lebih mudah menerima ajarannya. Sehingga, dengan strategi targeting yang demikian menghindarkan Rasulullah dari resiko penolakan yang tinggi terhadap dakwah Rasulullah serta menghindarkan dari ancaman keamanan dakwah di masa mulamula. Selain itu, kader-kader yang dihasilkan di masa mula-mula memiliki kualitas yang baik karena dipilih secara selektif sesuai dengan kapasitas dakwah saat itu, sehingga memudahkan Rasulullah untuk berdakwah di fase-fase berikutnya.

Kedua, pertimbangan kemenarikan struktural mad'uw secara jangka panjang. Dalam membidik mad'uw dakwah di Mekkah, Rasulullah bukan hanya memikirkan potensi penerimaan mad'uw dalam ajaran yang dibawanya, namun penulis melihat bahwa Rasulullah dalam memilih mad'uw juga mempertimbangkan aspek kemenarikan struktural mad'uw secara jangka panjang. Hal tersebut terkait dengan potensi keuntungan secara jangka panjang jika membidik segmen pasar tertentu. Hal tersebut terlihat dari pembidikan Abu Bakar, Khadijah dan orangorang terdekatnya sebagai mad'uw dakwah awal saat dakwah sirri di Mekkah.

Sahabat Abu Bakar dibidik sebagai mad'uw karena Rasulullah melihat potensi kemenarikan struktural dari karakteristik sahabat Abu Bakar. Abu Bakar dikenal oleh masyarakat memiliki kepribadian yang baik, pergaulan yang baik dan luas pandangannya sehingga banyak orang mengenal dan 
datang pada Abu Bakar untuk meminta pandangannya ataupun bekerja sama. Hal ini dipandang Rasulullah dapat menjadi potensi besar dalam mengembangkan ajaran Islam selanjutnya. Abu Bakar disebut Rasulullah sebagai orang yang mula-mula memperkuat ajaran Islam dan Rasulullah melihat potensi keberanian Abu Bakar untuk menjadi pilar awal dakwah mula-mula. Hal tersebut sebagaimana diungkapkan Haikal, "Pada waktu itu Abu Bakr b. Abi Quhafa dari kabilah Taim adalah teman akrab Nabi Muhammad Saw. Rasulullah senang sekali kepadanya, karena sudah diketahuinya benar ia sebagai orang yang bersih, jujur, dan dapat dipercaya. Oleh karena itu, orang dewasa pertama yang diajaknya menyembah Allah Yang Esa dan meninggalkan penyembahan berhala, adalah dia. Juga dia laki-laki pertama tempat dia membukakan isi hatinya akan segala yang dilihat serta wahyu yang diterimanya. Abu Bakr tidak ragu-ragu lagi memenuhi ajakan Muhammad dan beriman pula akan ajakannya itu. Keimanan sahabat Abu Bakar kepada Allah dan kepada RasulNya itu segera diumumkan oleh Abu Bakr di kalangan teman-temannya. la memang seorang pria yang rupawan. "Menjadi kesayangan masyarakatnya dan amikal sekali. Dari kalangan Quraisy ia termasuk orang Quraisy yang berketurunan tinggi dan yang banyak mengetahui segala seluk-beluk bangsa itu, yang baik dan yang jahat. Sebagai pedagang dan orang yang berakhlak baik ia cukup terkenal."

Sedangkan dakwah Rasulullah pada istrinya, Rasulullah melihat istrinya tersebut dapat memperkuat dakwahnya secara jangka panjang. Saat itu, Rasulullah memikirkan siapa yang dapat menenangkan dan menjadi tempat mencurahkan hatinya saat menerima tanggung jawab sebagai Nabi. Pada akhirnya Rasulullah menceritakan semua keluh kesah dan apa yang didapatkannya pada istrinya yaitu Khadijah.

Dakwah Rasulullah lebih menargetkan pada orang-orang terdekatnya yang telah dikenal dengan baik oleh Rasulullah bagaimana karakteristiknya. Rasulullah melihat bahwa membidik mad'uw yang sudah dikenal dapat membawa keuntungan bagi strategi dakwah sirri Rasulullah secara jangka pendek maupun jangka panjang. Mad'uw yang sudah dikenal oleh Rasulullah cenderung akan lebih mudah dipercaya Rasulullah untuk mendakwahkan Islam selanjutnya, menjaga rahasia selama masa dakwah sirri serta dapat memastikan keamanan dan kesuksesan selama dakwah sirri. Dengan suksesnya dakwah sirri, setidaknya Rasulullah memiliki orang-orang kepercayaan yang dapat menjadi kekuatan dakwah Rasulullah untuk berdakwah secara terang-terangan. Oleh karena itu, Rasulullah dalam targeting-nya sangat selektif untuk menghindari kegagalan dakwah sirri.

Ketiga, pertimbangan aspek moral yaitu potensi pandangan masyarakat jika Rasulullah membidik pasar. Dalam membidik mad'uw Rasulullah sangat memperhatikan moralitas dari mad'uw tersebut. Mad'uw dakwah sirri kecendrungan adalah orang-orang yang memiliki moralitas baik di masyarakatnya. Sehingga, dengan adanya orang-orang baik yang mengikuti ajaran Nabi Muhammad, maka masyarakat akan memiliki pandangan bahwa Islam merupakan ajaran yang baik. Berbeda halnya jika orang-orang yang masuk Islam mula-mula bukan berasal dari orang-orang baik, masyarakat akan berpandangan bahwa ajaran Islam bukanlah 
ajaran yang baik dan tidak akan disegani oleh masyarakat. Hal ini menjadi salah satu pertimbangan Rasulullah berdakwah secara selektif dalam memilih objek dakwah dan sangat mempertimbangkan aspek moral.

Dalam memilih mad'uw prioritas dakwah, Rasulullah juga mempertimbangkan aspek moral yaitu dampak pada pandangan atau situasi yang akan terjadi di masyarakat jika Rasulullah membidik pasar tertentu. Rasulullah cenderung membidik pasar secara selektif, dengan harapan agar tidak terjadi peperangan di masyarakat. Rasulullah mempertimbangkan karakteristik/moral masyarakat Arab yang sangat mempertahankan tradisi penyembahan berhala, masyarakat Arab bahkan tak segan-segan berperang untuk mempertahankan tradisi tersebut. Hal ini juga dilakukan oleh Sahabat Abu Bakar dalam berdakwah di masa dakwah sirri Mekkah, Abu Bakar tidak ke sembarang orang tetapi ke orang dekatnya dan yang memiliki moralitas baik, hal ini untuk menghindari peperangan dan menjaga keberlangsungan dakwah Islam.

\section{Kesimpulan}

Selama masa dakwah sirri, tiga tahun di Mekkah, Nabi Muhammad mampu mengajak beberapa orang dari keluarga intinya untuk masuk Islam yaitu Khadijah (istri Nabi), Ali bin Abi Thalib (kemenakan Nabi), dan Zaid bin Haritsah (anak angkat dan bekas budak Nabi), kemudian Nabi mengajak sahabat dekatnya yaitu Abu Bakar. Kemudian dari usaha dakwah Abu Bakar mampu mengajak banyak orang untuk masuk Islam, yang di antaranya adalah rekan-rekan dekat Abu Bakar.
Dari berbagai mad'uw yang kemudian masuk Islam, melalui proses perumusan segmentasi dan targeting pasar dakwah (mad'uw). Sehingga, dapat dikatakan bahwa dalam berdakwah Rasulullah tidak melakukan secara asal-asalan, Nabi Muhammad memilih mad'uw yang hendak didakwahi dengan proses dan pertimbangan yang ketat. Segmentasi yang digunakan oleh Nabi berdasarkan segmentasi demografis berdasarkan usia dan kelas ekonomi mad'uw, segmentasi psikografis berdasarkan kepribadian mad'uw, serta segmentasi perilaku berdasarkan pengetahuan yang dimiliki, tingkat militansi pada ajaran (tradisi) sebelumnya, potensi respon pada ajaran yang dibawa Nabi Muhammad. Dasar pengelompokan ini berangkat dari kondisi objektif karakteristik tiap-tiap kelompok yang ada pada masyarakat Arab, yang dipandang Nabi Muhammad memiliki signifikansi dalam tujuan dakwah di masa awal dengan strategi dakwah yang bersifat rahasia.

Selain itu, Rasulullah dalam memilih prioritas mad'uw cenderung menggunakan targeting pasar yang bersifat spesialisasi selektif. Artinya, Rasulullah membidik kelompok-kelompok masyarakat dengan karakteristik tertentu. Rasulullah lebih memilih berdakwah pada kelompok masyarakat dengan alternatif kriteria antara lain: memiliki hubungan kedekatan dengan Nabi Muhammad, golongan pemuda dan budak, golongan orang-orang yang memiliki kepribadian baik dan terbuka pemikirannya terhadap ajaran baru dan golongan yang berpotensi sikapnya tidak memerangi ajaran Nabi Muhammad.

Adapun pertimbangan-pertimbangan Rasulullah dalam menetapkan targeting 
pasar dakwah adalah: mempertimbangkan ukuran/pertumbuhan segmen, mempertimbangkan kapasitas internal Rasulullah selama masa dakwah sirri, mempertimbangkan aspek moral serta kemenarikan struktural segmen dalam dakwah secara jangka panjang. Di sini tidak ditemukan data terkait pertimbangan pesaing ataupun potensi kerjasama antar segmen yang dijadikan pertimbangan Nabi Muhammad dalam dakwah sirri di Mekkah.

Dengan mengkaji proses segmentasi dan targeting mad'uw yang dilakukan Nabi Muhammad selama dakwah sirri di Mekkah yang terbukti sukses dan memberikan kekuatan yang cukup besar pada masa awal dakwah, diharapkan dapat memberi wawasan tambahan bagi organisasi dakwah yang ada saat itu bahwa proses segmentasi dan targeting mad'uw penting dilakukan sebelum melakukan gerak dakwah, agar mad'uw yang dipilih tepat sehingga mempercepat proses dakwah. Namun, dalam melakukan proses segmentasi dan targeting mad'uw tidak harus sama persis seperti apa yang dilakukan Nabi, tapi perlu disesuaikan dengan keadaan yang dihadapi organisasi dakwah saat itu, selain itu teori segmentasi dan targeting yang dijadikan panduan tidak harus sama dengan Philip Kotler, bisa memilih teori yang lain yang dirasa sesuai.

\section{Bibliografi}

Al-Mubarakfuri, Syaikh Shafiyyurrahman. Sirah Nabawiyah. Jakarta Timur: Pustaka Al - Kautsar, 1997.

Arikunto, Suharsini. Prosedur Penelitian Suatu Pendekatan Praktik. Jakarta: PT. Rineka Cipta, 2006.

Armstrong, Karen. Muhammad Prophet For Our Time. Jakarta: Mizan, 2006.

Asriani, Dwi Wahyuni, "Strategi Positioning Radio Gema Annisa Sebagai Radio Dakwah." Skripsi, UIN Syarif Hidayatullah, Jakarta, 2009.

Binti Abd. Majid, Mariam. "Adaptasi Kaedah Pemasaran Dalam Perancangan dan Pengurusan Dakwah." Jurnal International Research management and innovation Conference, 2014.

Haekal, Muhammad Husain. Sejarah Hidup Muhhamad. Jakarta: PT. Mitra Kerjaya Indo, 2011. Ibnu Ishaq dan Ibnu Hisyam. Sirah Nabawiyah (Sejarah Lengkap Kehidupan Rasulullah). Jakarta Timur: Akbar Media Eka Sarana, 2016

Kotler, Philip. Manajemen Pemasaran Edisi kedua belas jilid 1. Jakarta: PT. Indeks, 2008. - Manajemen Pemasaran Edisi I Marketing Manajemen 9e. Jakarta: PT. Prenhalindo, 1997. . Dasar-Dasar Pemasaran Edisi V. Jakarta: Intermedia, 1991. . Manajemen Pemasaran Edisi XI. Jakarta: PT. Indeks kelompok gramedia, 2005.

Al-Ghadban, Syaikh Munir Muhammad. Manhaj Haraki: Strategi Pergerakan dan Perjuangan Politik dalam Sirah Nabi Saw. Jakarta: Rabbani Pers, , 2009.

Shihab, M. Quraish. Membaca Sirah Nabi Muhammad Saw. Dalam Sorotan Al-Qur'an Dan Hadits-Hadits Shahih. Tanggerang: Lentera Hati, 2011.

Sugiyono. Memahami Penelitian Kualitatif. Bandung: CV. Alfabeta, 2008. 
Alan Surya \& Wahanani Mawasti

Sulaiman, Anggi. "Strategi Pemasaran Produk Tabungan Wadi'ah Bank Mega Syariah." Skripsi UIN Syarif Hidayatullah, 2011. 